\title{
Honouring the Dual Commitment: Remittance Strategies of Ghanaian Migrants in Amsterdam
}

DOI: $10.11567 /$ met.30.2.4 UDK: 314.74(492 Amsterdam=667):339 Izvorni znanstveni rad Primljeno: 14.08.2014. Prihvaćeno: 02.11.2014.

Ntokozo Nzama

ntokozo.nzama1@gmail.com

\section{Brij Maharaj}

Department of Human Geography, University of KwaZulu-Natal, Durban maharajb@ukzn.ac.za

\section{SUMMARY}

This paper seeks to understand the rationale behind the practice of remittances and to examine its impact on the living standards and conditions of Ghanaian remitters living in Amsterdam, the Netherlands. This study investigates how remitters are able to sustain their lifestyles in a foreign country, and the sacrifices and compromises made in terms of their dual commitment to support families in Ghana and in the Netherlands. A qualitative approach using in-depth interviews was adopted in order to give research participants an opportunity to talk broadly about their lived experiences as Ghanaians residing in a foreign country and the challenges associated with sending remittances. Push factors such as political unrest, poverty, low income, and unemployment influenced movement out of Ghana. A better quality of life (better paying jobs, improved qualifications) was the major pull factor that attracted migrants to the Netherlands. Remittances from migrants in the Netherlands supported the welfare of many households in Ghana, especially in terms of improved standards of living and better access to health care and education. Sending remittances is not "a feel good gesture" only, but an obligation to the family members back in Ghana. This study shows that there were major compromises and trade-offs in terms of migrant lifestyles because of their dual commitments.

KEYWORDS: migration, remittances, dual commitment, Ghana, the Netherlands

\section{INTRODUCTION}

In 2013, the United Nations estimated that about 232 million international migrants lived outside their countries of birth. About 81.9 million 
migrants from the South were living in the North, ${ }^{1}$ and are a major source of remittance flows. Remittances can be defined as "money and goods that are transmitted by migrant workers" employed beyond the borders of their country of origin (Adams, 2009: 93). The World Bank estimated that remittance flows to the South in 2012 was $\$ 401$ billion. ${ }^{2}$ In contrast to the other papers in this theme issue, this paper focuses on migrant remittances from the Netherlands to Ghana. ${ }^{3}$

There are three main themes in the published literature on remittances (Ponce, Olivié and Onofa, 2008): 1. analysis of the motives to remit which include altruism, exchange, insurance, investment (Vanwey, 2004; Amuedo-Dorantes and Pozo, 2006; Poirine, 2006); 2. research on transferring channels and costs, and policies to reduce these charges (Pieke, van Hear and Lindley, 2007; Freund and Spatafora, 2008); 3. the extensive literature on the impact of remittances (Adams, 2009; Page and Mercer, 2012; Bertoli and Marchetta, 2014).

For many African families, remittances from international migrants are vital for survival and a major source of income to pay for basic needs such as housing, expenses, and school fees (Adepoju, 2008). However, "[r] emittances to sub-Saharan Africa make up a central yet poorly understood outcome of the migration process" (Osili, 2012: 68). This paper seeks to understand the rationale behind the practice of remittances and to examine the impact of this dual commitment of Ghanaian remitters living in Amsterdam, the Netherlands. Dual commitment means that participants not only have to take care of their immediate family in the Netherlands, but also of relatives in Ghana. This paper will add to the emerging scholarship on remittances from the Netherlands to Ghana (e.g. Kabki, Mazzucato and Appiah, 2004; Mazzucato, Boom and Nsowah-Nuamah, 2008; Mazzucato, 2009, 2011; Visser, Bailey and Meijering, 2014). In addition to migration and remittance decisions, an important focus of this paper will be on the strategies adopted by migrants and the trade-offs, compromises and sacrifices made in order to fulfill their dual commitments in their home and adopted countries, which is an understudied field (Lindley, 2009).

http://esa.un.org/unmigration/wallchart2013.htm (12 June 2014).

2 http://siteresources.worldbank.org/INTPROSPECTS/Resources/334934288990760745/MigrationDevelopment Brief20.pdf (12 June 2014).

3 Some of the data presented in this paper was used by Ntokozo Nzama in her Master's thesis Keeping Body and Soul Together - Migration, Remittances and Livelihood Strategies of Ghanaians in Amsterdam South East (Bijlmer), Faculty of Social Sciences, Radboud University, Nijmegen (2012). 
Datta et al. (2006: 26) have argued that "there has been little research on the costs of remitting at a personal level of the migrants involved in the sending". This paper will reveal that the migrants from Ghana were not being employed in jobs according to their experience, skills and qualifications. They experienced deskilling, and were employed in menial, labour intensive activities, and a possible reason for this was attributed to their lack of fluency in the Dutch language. Theoretically, this study is influenced by the new economics of labour migration approach which contends that while economic motives and individual decisions are important, social entities, such as the household, play a major role in influencing the decision to move (Stark and Bloom, 1985; Stark, 1991; Taylor, 1999; Jennisen, 2007). According to Stark (1991: 3) "this premise shifts the focus of migration research from individual independence to mutual interdependence. Various implicit and explicit intra-family exchanges, such as remittances are thus integral to migration, not unintended by-products of it". Hence, while the economic impacts are important, remittances serve to preserve links between migrants and those at home (Karraker, 2013).

This paper is divided into four sections. The first section explains the methodology adopted and describes the study area; the second section presents a profile of migrants and their reasons for moving; the motives for remittances is the theme of the third section; the final section analyses the dual commitments of migrants and its implications.

\section{STUDY AREA AND METHODOLOGY}

Bijlmer in South East Amsterdam was selected as the research site because it hosts many Ghanaian migrants, who came to the Netherlands in large numbers in the 1990s and 2000s. Many Ghanaian migrants settled in a relatively new complex with huge apartment blocks in the Bijlmer in the South-Eastern part of the Amsterdam metropolis (Dietz et al., 2011). It is estimated that the majority of Ghanaian remitters in the Netherlands send about $€ 260$ to their families in their country of origin about nine times a year. This is estimated to be about $€ 40$ million a year sent by all Ghanaian migrants in the Netherlands (Orozco and Mohogu, 2007: 1).

Ghanaians in Amsterdam have a reputation for their commitment to religion, with many belonging to Pentecostal churches (Dietz et al., 2011). The Ministry of Internal Affairs stated that in the year 2000 there were approximately 15,610 "legal" Ghanaians in the Netherlands with about one third living in Amsterdam-Bijlmer and "a few thousand" were living there 
without documentation (Choenni, 2002, in Dietz et al., 2011: 134). In 2005 the number of documented Ghanaians in Amsterdam exceeded 10,000 (Gemeente Amsterdam, 2006: 2). Dietz et al. (2011) noted that Ghanaian migrants living in Amsterdam were mainly coming from the Ashanti area. Almost all the immigrants have gone to school and many had tertiary qualifications, but they could not find jobs in the Netherlands that could enable them to utilize their skills and qualifications.

This study adopted a qualitative approach in order to understand the lived experiences "from the inside out", from the point of view of the people who participated in this case study, i.e. Ghanaian migrants in the Netherlands (Flick, von Kardoff and Steink, 2004: 18). It seeks to contribute to a better understanding of social realities and provide insightful information, and a better understanding of the lives of the remitting Ghanaian migrants. The purposive sampling technique was used to select the research participants who straddled generations of Ghanaian immigrants as categorized in Table 1. Purposive sampling ensures that the "sample is composed of elements that contain the most characteristics, representative of typical attributes of the preferred population" (Teddlie, Charles and Tashakkori, 2009: 170).

N. Nzama was introduced to a prominent member of the local Presbyterian Church who was the leader of the Women's Group in the church. She and the Pastor introduced the study to about 100 members of the church at a Sunday service on the 8th January 2012. The Pastor requested members to indicate by a show of hands if they were willing to participate in this study. From the initial 45 members who volunteered, seventeen participants who fulfilled the study criteria were selected from the Presbyterian Church. An additional five participants were selected, who were second generation immigrants, volunteering as Sunday school teachers at the church. Eight more participants showed interest in the study and were included, bringing the sample to size of 30 participants.

The profile of the participants included different age groups, gender, occupations and citizenship status as illustrated in Table 1. Citizenship status determines access to state resources. To ensure anonymity and confidentiality, participants were allocated the following codes (PM1, CCC) ${ }^{4}$, as reflected in Table 1.

${ }_{4}$ E.g. PM1, CCC refers to participant $(\mathrm{P}) 1$ who is male (M), and works as a cleaner in the city centre (CCC), and so on. 
Table 1. Characteristics of the research participants

\begin{tabular}{|c|c|c|c|c|c|}
\hline No. & $\begin{array}{l}\text { Participant } \\
\text { Gender }\end{array}$ & Age & Employment & $\begin{array}{c}\text { Duration } \\
\text { of stay in } \\
\text { Netherlands } \\
\text { (years) }\end{array}$ & Status \\
\hline 1 & PM1 & 30 & $\begin{array}{l}\text { Cleaner city centre } \\
(\mathrm{CCC})\end{array}$ & 5 & $\begin{array}{l}\text { Study } \\
\text { Permit }\end{array}$ \\
\hline 2 & PM2 & 55 & $\begin{array}{l}\text { Technical Assistance } \\
\text { Mechanics company (TA) }\end{array}$ & 30 & $\begin{array}{l}\text { Dutch } \\
\text { Passport } \\
\text { (DP) }\end{array}$ \\
\hline 3 & PF3 & 53 & Domestic Work (DW) & 30 & DP \\
\hline 4 & PM4 & 35 & $\begin{array}{l}\text { Opened Travel Agency } \\
\text { in Bijlmer (OTA) }\end{array}$ & 18 & DP \\
\hline 5 & PM5 & 32 & $\begin{array}{l}\text { Aalsmeer Flower } \\
\text { Auction (BVA) }\end{array}$ & 12 & $\mathrm{DP}$ \\
\hline 6 & PM6 & 40 & $\begin{array}{l}\text { Cleaner train station } \\
\text { (CTS) }\end{array}$ & 22 & $\mathrm{DP}$ \\
\hline 7 & P F7 & 49 & Domestic work (DW) & 20 & $\mathrm{DP}$ \\
\hline 8 & PM8 & 36 & Printing company (PC) & 4 & $\begin{array}{l}\text { Awaiting } \\
\text { Citizenship }\end{array}$ \\
\hline 9 & PF9 & 42 & Domestic Work (DW) & 17 & $\mathrm{DP}$ \\
\hline 10 & PM10 & 49 & $\begin{array}{l}\text { Bloemenveiling } \\
\text { Aalsmeer (BVA) }\end{array}$ & 5 & DP \\
\hline 11 & PM11 & 39 & Printing company (PC) & 9 & DP \\
\hline 12 & PF12 & 26 & Domestic Work (DW) & 3 & $\begin{array}{l}\text { Work } \\
\text { Permit }\end{array}$ \\
\hline 13 & PF13 & 45 & Domestic Work (DW) & 15 & DP \\
\hline 14 & PM14 & 45 & Cleaner Schiphol (CS) & 20 & $\mathrm{DP}$ \\
\hline 15 & PF15 & 39 & $\begin{array}{l}\text { Domestic Work } \\
(\mathrm{DW})\end{array}$ & 16 & $\mathrm{DP}$ \\
\hline 16 & PF16 & 39 & Travelling agency (OTA) & 9 & $\mathrm{DP}$ \\
\hline 17 & PM17 & 32 & $\begin{array}{l}\text { Schiphol (KLM) baggage } \\
(\mathrm{SKB})\end{array}$ & 12 & DP \\
\hline 18 & PF18 & 38 & Domestic Work (DW) & 10 & $\mathrm{DP}$ \\
\hline 19 & PF19 & 47 & Domestic Work (DW) & 20 & $\mathrm{DP}$ \\
\hline 20 & PM20 & 32 & $\begin{array}{l}\text { Technician mechanic } \\
\text { company (TA) }\end{array}$ & 2 & $\begin{array}{l}\text { Awaiting } \\
\text { Citizenship }\end{array}$ \\
\hline 21 & PF21 & 43 & Domestic Work (DW) & 20 & DP \\
\hline 22 & PF22 & 45 & Domestic Work (DW) & 22 & DP \\
\hline 23 & PF23 & 26 & Student $(S)$ & 21 & $\mathrm{DP}$ \\
\hline 24 & PM24 & 19 & Student (S) & Born in NL & $\mathrm{DP}$ \\
\hline 25 & PM25 & 22 & Student (S) & 18 & $\mathrm{DP}$ \\
\hline 26 & PF26 & 25 & Student (S) & Born in NL & $\mathrm{DP}$ \\
\hline
\end{tabular}




\begin{tabular}{lcclcc}
\hline No. & $\begin{array}{c}\text { Participant } \\
\text { Gender }\end{array}$ & Age & Employment & $\begin{array}{c}\text { Duration } \\
\text { of stay in } \\
\text { Netherlands } \\
\text { (years) }\end{array}$ & Status \\
\hline 27 & PM27 & 23 & Student (S) & Born in NL & DP \\
\hline 28 & PM28 & 48 & Cleaner Schiphol (CS) & 23 & DP \\
\hline 29 & PM29 & 39 & Cleaner Schiphol (CS) & 13 & DP \\
\hline 30 & PM30 & 42 & $\begin{array}{l}\text { Cleaner at train station } \\
\text { (CTS) }\end{array}$ & 20 & DP \\
\hline
\end{tabular}

This study adopted a micro-level ethnographic approach (McHugh, 2000). A total of 30 in-depth, qualitative interviews were conducted with Ghanaians living in the Bijlmer who were above the age of 18 years in order to increase the probability of the participants being employed, and thus sending remittances to Ghana. In-depth interviews gave the research participants an opportunity to talk broadly about their lived experiences as Ghanaians residing in a foreign country. The interviews took place at different locations such as the church, popular Ghanaian shopping areas in the Bijlmer and in some of the participants' homes. The interviews ranged between forty five to sixty minutes. The participants were able to share their migration motives and speak freely about how they organized their lives, and the strategies they adopted in order to honour their dual commitments. As McHugh (2000: 72) has argued, ethnographic approaches "capture the varying tempos and rhythms of movement and connection [...] reveal lived experiences" with "implications for both people and places".

\section{PROFILE OF MIGRANTS}

The participants in the study came from different socio-economic backgrounds in Ghana, ranging from relatively poor homes to middle class families. Two-thirds of the participants came from families with unemployed parents, or one working parent. Four out of thirty participants came from middle class families in Ghana as they were the children of farmers, shop owners, and teachers:

After secondary school my father was a bit rich, he was a farmer so he had some money. He said I want you to go to Europe to have a different life something like that and come back home. So when I came here I decided not to go home just like that. (PM2, TA) 
Some arrived in the Netherlands to study with European scholarships and decided to try and make a living in that country. Others came from poor backgrounds and had a Dutch partner who sponsored their travelling costs and took care of their daily needs while they sought citizenship, as well as employment:

I came here through marriage as my wife was already here, and of course to try and make a living [...] she was working so I was able to come here. You know it's difficult to find a job here, so my wife was supporting me when I first arrived. (PM11, D)

It is important to note that the majority of participants were Dutch citizens. During the time of the interviews all participants were employed in temporary, non-professional jobs. Participants indicated that it was relatively easy to secure non-professional jobs as there were employment agencies that were able to assist them. The participants were employed as domestic workers, some were cleaning the streets and train stations, and others worked in packaging factories. This is in spite of the fact that some of the participants possessed college diplomas obtained in the Netherlands and Ghana. There were "complaints from within the Ghanaian community that it is difficult for them to use their diplomas, and that it is much easier to do so in Great Britain which has resulted in a steady outflow of people from Amsterdam to London" (Dietz et al., 2011: 135). The next section sheds light on the reasons why these migrants came to the Netherlands.

\section{REASONS FOR MIGRATING}

Three main reasons were given for migrating from Ghana: internal conflict and political instability; escape from poverty; improving qualifications.

\section{Internal conflicts and political instability}

Migration can be influenced by political instability such as internal conflict within the country as well as poor human rights records. The first generation immigrants were pushed by unfavourable living conditions as a result of internal conflict around the 1980s:

In Africa [...] no condition is permanent, you see there will be a new government and all the riches will just go. My father was a very rich man but later he became poor. Because in Ghana they can change the currency any time they like [...] they make a Coup d'état [...]. So during 1981 at that time Ghana was really terrible [...] So I decided to stay here and you know make my life here. (PM2, TA) 
Unstable government, police brutality and the interrogation of civilians led to emigration out of Ghana as people feared for their lives because of the dictatorial regime in the 1980s.

A female participant stated how she had to initially seek political asylum in Belgium due to political turbulences in Ghana:

When I moved from Ghana I went to Belgium, that time there were problems in Ghana so I was seeking political asylum, before there was no democracy, there were police everywhere in Ghana and they were torturing people and they were leading to war. (PF19, DW)

The failure of the ruling regime to deliver services to people as well as mismanagement of funds and corruption within the government also facilitated an exodus. People felt helpless to secure a future in an unstable country. The search for a better and more secure livelihood drove migratory movements to the Netherlands:

I came here for my own interest [...] because I wanted a different life. Europe is better than Africa. The political scene is different in Europe, look in Africa how people kill their brothers. Look how the government in power uses the money, look at the poor people. In Europe, if you are sick the government cares for you, in Africa if you are sick who will take care of you. (PF7, DW)

The political scene in Ghana in the 1980s led to emigration as people feared for their lives and their future. Others migrated to the Netherlands to escape from poverty.

\section{Escape from poverty and seeking economic prosperity}

The decision to migrate is frequently a personal one, often driven by economic necessity and the need to take care of family members back home. Participants migrated from Ghana to escape from poverty and improve their living standards.

It appeared that migrating to the developed world was a strategic move to break the cycle of poverty for their households in Ghana as well as for the individual migrant. About half of the participants mentioned that they were the sole bread winners in their families both in the Netherlands and in Ghana. If they were to stop sending remittances, their families in Ghana would suffer as they did not have any other source of income.

A participant who had worked in a bank in Ghana, and who had just started a travel agency in Bijlmer, explained how migrating to Europe was a survival strategy for his family as his father lost his employment: 
As Ghanaians we believe in the extended family, I am the first born of seven children. My mother was a teacher [...] and my father was in the coco industry. He was a director in the coco board, due to some political reasons he had to retire prematurely [...] I was working at the bank in Ghana [...] my father called me and told me [...] that my mother's salary cannot take care of the family and that I had to resign. As a first born I had to sacrifice because it was going to be difficult in Ghana in the coming years [...] my mother was the only one working and her salary could not take care of the family. So I came here so I could support my family. (PM4, OTA)

Hence, migrating to Europe was a household decision, directly or indirectly. Migration was not concern just for an individual's well-being but also for the family in the country of origin:

The thing is that if you are an African and you come to Europe, then you have a task which is to help the needy within your family. That is one of our burdens, it's one of our goals when we come here. You are not here for yourself, you are here also for your family. (PM11, PT)

The participants came from different family backgrounds in Ghana but they all appeared to have the same goal that brought them to Europe - to improve the quality of life of their families in the country of origin. Others migrated to the Netherlands to improve their qualification.

\section{Improving qualifications}

Some of the participants indicated that they had come to the Netherlands to advance their education. But due to financial constraints and obligations in the Netherlands and Ghana, they were no longer able to continue with their tertiary education studies:

To get an education here it is difficult, if you have work you don't feel the need to go to school anymore. There is no time and money to go to school, what will happen to the bills and my family if I stopped work to study, it will be very hard. (PF12, DW)

Others founded families in the Netherlands and hence had more financial responsibility and could not migrate to countries where they had wished to continue with their education, which further shattered their academic dreams:

I wanted to migrate so I could continue with my education. I really wanted to continue my education. I tried to enter a University in Ghana and could not get admission, at that time they only had three Universities and every year it was full [...]. So when I came here I wanted to level with them, my destination was 
Canada because there it would have been possible to also focus on my education. I was planning to work so I can take care of my family then, also further my education, but I could not go to Canada. I have a family here now. (PM14, CS)

Even those who had completed their studies experienced difficulties in obtaining employment. One of the participants came to the Netherlands through a European scholarship. He indicated that he had migrated to improve his education as well as to gain international experience by working in his professional field in the Netherlands. Although he was a qualified engineer, he experienced difficulty in obtaining employment:

I have been trying to find a professional job, it's very difficult [...] Even though

I got the qualification here I could not get a job related to my specialization [...]

I was given one year to get a job and that one year is not renewable you know, it passed without me being able to secure a job. Thereafter I had to look for other odd jobs to keep body and soul together [...]. (PM1, CCC)

The above case is also a good example of de-skilling or skills mis-match. The engineer believed that he was disadvantaged because of a perceived inability to speak the Dutch language:

I mean when I got here I was hoping to get [...] international experience as Ghana was in need of the skills. With my qualification I don't understand how I was not able to get a job. Maybe [...] my inability to speak their language could have an effect on their non-replies. I have applied to so many companies I'm even tired. I just have to go back home. (PM1, CCC)

It was evident that the country where tertiary level qualifications were obtained had no relationship with securing professional employment, as both Dutch and Ghanaian educated migrants did not have professional jobs in the Netherlands. This is illustrated below by a thirty seven year old male from Ghana who studied travel and tourism:

You may have the qualification but the jobs that you need, you will not get it even if you have the qualification. When I was looking for a job that I am qualified for, I applied through a job agency, they asked me a question whether I was born here, I said no. They told me that that job is reserved for someone who was born here. As I told you, you may have the academic qualification but the job offer does not suit you as a citizen/foreigner. (PM4, OTA)

There were several reasons that have led to the current migration to the Netherlands but the common factor was to secure a livelihood for themselves and to support their families in Ghana. The next section focuses on the motives for sending remittances. 


\section{MOTIVES FOR SENDING REMITTANCES}

The main reason for migrating to the Netherlands was to work and send money to the families in Ghana. Almost half of the participants were the sole bread winners in their families, both in the Netherlands and in Ghana. They indicated that if they did not send remittances, their families in Ghana would be destituted. They sent remittances because they cared about their families. There was also a lot pressure, obligation and expectations to send money home.

One of the participants interviewed was a thirty year old male who had a Master's degree in Petroleum Engineering and has been in Amsterdam for five years. He earns his income through cleaning the streets in the city of Amsterdam, another example of de-skilling. When questioned about sending remittances to Ghana he responded as follows:

[...] they [family in Ghana] are one of the reasons I am working [...] doing these odd jobs also, also I work to survive [...] it's always been like that [...] I am responsible for the people back home. I have been responsible since, you know, before coming over here I provided for my family. It's not something that I can stop, I will continue to do that, as a man it is your responsibility, you cannot run away from it. (PM1, CCC)

Amongst those interviewed was a forty five year old male who had previously worked as a police officer in Ghana. He had come to Europe fifteen years ago and had stayed in Belgium for ten years. He has lived in the Netherlands for five years, working at the Aalsmeer flower distribution company in Amsterdam. His mother in Ghana depended solely on his remittances:

It is my responsibility to send money home because of my mother. If I cannot send money home for whatever reasons, it will be hard. My mother will not be able to survive; she does not have any other source of income besides what I send for her. There is no way for old people to survive, they need their children to help them like I do. (PM10, BVA)

Some participants were investing in the education of their younger siblings in order to reduce their financial responsibility in the future. They indicated that helping their immediate and extended family members to improve their qualifications will enable them to get better jobs in future and could break the dependency cycle on remittances.

A participant mentioned that he had to borrow money from fellow countrymen in the Netherlands in order to send remittances in times of need: 
My nephew wants to join the military so he called me and told me that he has to go for the medical and pay for a few things [...] I did not have money so I borrowed from a friend [...] so that I don't worry any more with him. (PM16, CTS)

Second generation migrants did not have a strong connections with the family members in Ghana, and there was no strong obligation to send remittances. However, there was an interesting case where the mother of one of the student participants left the Netherlands two years ago after she had an injury at work:

Now that my mother is there for almost two years and I send her money. I know how it works now. She was sick, she had a small accident at her job [...] so we decided that she should go home for environment change, maybe she will be better there. But I had never sent money for my uncles and aunts. (PF26, S)

She indicated that she was able to assist her mother with support from other siblings in the Netherlands. She explained further that she now understood the value of remittances:

I never knew how it is to have someone in Africa to send the person money every month. Now I really feel how the other people have been feeling all these years. Our parents had to work hard to take care of us and our grandparents and sending money home. I had never had that feeling before. But now I'm doing the same thing to my mum so I'm feeling it now. But sometimes when my mum asks for money, I tell her no, we have to pay the bills first then if there is some left then you will hear from us. (PF26, S)

The participants pointed out that remittances sent to Ghana were used for different household essentials for survival which included: bills such as electricity, water, house maintenance, and clothing; food, health care, and children's tuition fees. A major challenge was the dual commitments to family in Ghana and the Netherlands respectively, and this is the theme of the next section.

\section{DUAL COMMITMENTS OF REMITTERS AND THEIR IMPLICATIONS}

This section highlights the daily lived experiences that remitters encounter, and the sacrifices that have to be made to send remittances to Ghana. Migrants had to evaluate their personal circumstances in order to develop remittance strategies to send money to Ghana. Factors such as the presence of immediate family members and other financial commitments in the 
Netherlands (such as rent, insurance, food and other household bills), had a strong influence on the frequency and amount of money remitted.

The participants had a commitment to family in Ghana as well as in their adopted country, the Netherlands, where many were married and had children and the associated responsibilities. Some participants indicated that this dual commitment was strenuous and many sacrifices had to be made:

Its strains me [...] and with Africans you know [...] we have more than immediate family but also the extended family as well. You have someone who helped you come this far, in your own small way you need to be able to touch someone's life [...] You have to find means to help regardless of how hard the matters are and it's really stressful [...] But I can never forget my people, they are part of me. (PM1, CCC)

Although some participants indicated that they could send remittances only bi-monthly and others could when the need arose, they also highlighted the difficulty of sending remittances and coping with their daily lives in the Netherlands. This was illustrated in the case of a participant who had to assist even when he was a student on scholarship:

It is stressful because [of] an expectation to help and the expectation is too high. I have family in Ghana that I help a lot. If I don't try and having people know very well I have a job [...] they know that if I promise them something I had to give them. Even when I was schooling I had to help a lot, that's how hard it was [...] You know, I was on a scholarship, sometimes they give you money and you have to give money to the poor people back home and then the school will be on you, they were asking where is the money? (PM1, CCC)

Many remitters were forced to live a compromised lifestyle in the Netherlands. They often bought the cheapest food items, spent less on clothes and were forced to take up any available employment. They lived simple lives and could not afford to go out for dinners or have any kind of leisure activities such as vacations. Many were forced to take on a second job and to work extra hours in order to survive. This stress and sacrifice was attributed mostly to moral obligations and responsibility to one's family. The reasons behind this level of commitment are many, but the most important one is the strength of family ties and feelings of obligation and willingness to help out.

Equally, some participants did not view sending remittances as a compromise but rather an obligation. It seemed the word compromise had a negative connotation, but rather the term obligation was preferred as they felt that it was their responsibility to take care of those in their country of 
origin. There seemed to be a feeling of relief and peace of mind if they were able to help those at home:

If I send money home, it has become part of me. I don't think that I am compromising anything, it's my obligation. You know I feel like if you are not okay, I'm not okay [...] I know it is difficult, but it has always been difficult, but it also shows the kind of love you have for your people [...] When people need it and I have it, I have to give it to them. I don't think about how much it affects me. They are one of the reasons I am working, know, doing these odd jobs also. (PM17, SKB)

Participants indicated that the increasing cost of living in the Netherlands made life more difficult for those who were committed to supporting families in two countries (RM5, BVA). As the remittances were primarily used for basic household expenditure and everyday subsistence consumption, if it was stopped it would have a negative impact on the livelihoods of the receiving families.

Some participants stated that they felt as if they were caught up in-between the Netherlands and Ghana. They cannot abandon those at home; there is a notion of empathy as well as compulsion that drives the remittances flow to Ghana. If the remitters are unable to send money home, the phone calls and text massages will not stop:

Sending money home has been a thing that I have to do, if not I would have been a millionaire, because they call and they say the old lady is sick, please send money, I'm in trouble, can't you help me, there are so many requests. (PM10, BVA)

Some participants indicated that they had developed strategies so that they could be able to send remittances and still take care of their daily needs in the Netherlands. More specifically, their focus was on managing personal finances, extra working hours, and establishing and nurturing social ties.

\section{Managing personal finances}

It was evident that remittances were not sent without planning. Remitters had to assess their socio-economic circumstances which invariably determined the amount and flow of remittances. A lot of sacrifices had to be made as participants had to devote part of their salaries to take care of people in Ghana. Frequently, they were unable to fulfill all their needs in the host country and they had to cut down on their monthly expenditure in order to remit: 
There is no one else that can help them, at this other point I had to call the insurance here with my wife and we told them that we could not pay that month because there was a demanding situation at home [in Ghana]. (PF15, DW)

The participants mentioned how they had to manage their finances in order to be able to sustain their lifestyles in the Netherlands and also be able to remit. In order to be able to fulfill this double commitment, they had to prioritize what they spent money on, where they did their grocery shopping, and the quantity and quality of food they consumed. One of the female migrants explained this process:

I have to manage how we eat and how we spend so I can send a little bit of money home. I am the only person who can take care of my family at home. (PF12, DW)

The participants indicated that if they spent less on food and other necessities, it was possible to remit. It was important to prioritize and ensure that monthly bills in the Netherlands were paid:

I manage sending money home. I plan it in such a way that I can still pay my bills here [...] first rent, insurance [...] I have to manage how we eat and how we spend so I can send a little bit of money home. I am the only person who can take care of my family at home. I feel the strain of sending money home, but what can I do? I have to compromise my life here. I cannot get, maybe, my daughter what she wants, to buy something that the other kids have, like nice phone, shoes, whatever, because I don't have enough money and I still need to support my family at home. (PF7, DW)

Even though the participants occupied non-professional jobs, they managed their spending patterns. Hence, the effect of sending remittances results in the reduction of their standard of living in the Netherlands, and many had to work extra hours or take on a second job to survive.

\section{Extra working hours and type of employment}

Many migrants go to considerable lengths to meet remittance requests, most often by working extra hours, but also by delaying or omitting to pay bills, or by borrowing money. As a result of working over time they face many challenges which could have been avoided if they supported only one family in the Netherlands:

Sometimes if you do eight hours you can't survive with that and you need maybe two more hours which is still allowed, but you cannot exceed ten hours [...] I work over time so I can send money home. (PM10, BVA) 
Some participants mentioned that they would do any kind of job to ensure that there was some money to remit. Families in Ghana depend on them so they need to do whatever it takes to take care of those at home:

You don't have to select types of jobs, you need to take whatever comes your way.

You need to do anything to make money; you don't have to mind because sometimes there is pressure on you [...] people in Africa are poor, they depend on us all the time, they can't ask other people because they also don't have money. (PM30, CTS)

The remitters had to make numerous sacrifices in order to send remittances home. As highlighted earlier, the participants had low-paying jobs which increased their vulnerability in meeting their dual commitments. Well established social networks provided some support.

\section{Social ties}

The Amsterdam-based Ghanaians have well developed social networks that usually take the form of associations offering support to survive the daily challenges of living in the Netherlands. The main social network revolves around church (Presbyterian), and ethnic associations which also provide emotional support. All participants mentioned that the church was the main support structure where they could speak to someone if they had any problems (this excluded financial support). For example, if one of the church members was unemployed, then he/she can get referrals from other members of the congregation:

Thank God for this church [...] if you tell them you have this kind of problem, by the end of the church service someone will come to you and help you. If they know your problem, they come to your aid. That's how we live here. We help each other here in the church. I can always go to the church members if I need help. (PM29, CS)

While the Ghanaian migrants were well known for assisting other community members, this generosity was slowly being eroded, especially in terms of financial support. Participants indicated that they would not lend money to their compatriots in the Netherlands as they were also facing the same financial challenges, but more importantly because of a lack of trust within the community:

The people have changed [...] the generosity is still there but it's not the same as a decade ago. But one of the major reasons is, people are going through economic hardships and job uncertainties, people do not know if they will have a job tomorrow so it's hard to help. (PM6, CTA) 
Hence, there were changes in the way that the community members interacted with each other. The participants also complained that Ghanaians lived their lives individualistically and did not interact much with fellow country folk. Community cohesion was declining. They had to make appointments to meet with fellow country folk, which they never did at home. This was most probably related to higher levels of integration into Dutch society and the decline of traditional Ghanaian value systems.

\section{DISCUSSION AND CONCLUSION}

It was evident from this study that push factors such as political conflicts, poverty, low income, unemployment, human rights violations, and corruption influenced movements out of Ghana. The search for a better quality of life (higher paying jobs, improved qualifications) was the major pull factor that attracted migrants to the Netherlands, which also enabled some remittances to be sent. In the majority of cases, the decision to move was consciously and strategically made in consultation with the family, driven by economic necessity and the need to take care of household members in Ghana. Hence, "remittances became central to migration decisions, reflecting an implicit contract between the migrant and those left behind" (Lindley, 2009: 40). In this context, the new economics of labour migration approach was relevant for this study (Stark and Bloom, 1985; Stark, 1991).

It was apparent that remitting was a long standing practice, with both males and females (and some being students) being committed to providing support, notwithstanding their personal circumstances. Remittances from migrants in the Netherlands supported the welfare of many households in Ghana, especially in terms of improved standards of living and better access to health care and education. This has been referred to in the literature as family remittances (Goldring, 2004). The main motivation for sending remittances was the obligatory caring for loved ones at home or altruism (Porine, 2006). Those who had children and parents living in Ghana sent regular remittances.

Most migrants occupied non-professional jobs, which in many instances was not commensurate with their qualifications, skills and training, with short term contracts, which affected the amount and frequency of remittances. Migrants experienced de-skilling or a skills mis-match, which was a form of disempowerment for those with post-graduate qualifications and training, who were forced by circumstances to work as labourers, doing menial tasks. The most prominent reason for educated migrants not being 
able to secure professional employment in the Netherlands was attributed to their inability to speak the Dutch language fluently. Hence, African accents were perceived to be a form of prejudice in one of the most liberal democracies in the European Union.

Most of the participants worked seven days a week, and some had to take on a second job in order to be able to remit. There were major compromises and trade-offs in terms of migrant lifestyles because of the dual commitments, and this paper highlighted some of the "personal costs" of remitting (Datta et al., 2006). They were unable to live the life which they had imagined in the developed world as they were committed to supporting families in both countries, and had to be frugal in personal spending priorities by "minimizing consumption levels" (Datta et al., 2006: 26). A key focus of this paper was on how remitters were able to sustain their lifestyles in a foreign country, and the sacrifices and compromises made in terms of their dual commitments to support families in Ghana and the Netherlands. The participants were not able to make decisions that would only benefit themselves, but rather for the benefit of families in the Netherlands as well as in Ghana.

\section{REFERENCES}

Adams, R. H. Jr. (2009). The Determinants of International Remittances in Developing Countries, World Development, 37 (1): 93-103, doi: 10.1016/j.worlddev.2007.11.007.

Adepoju, A. (2008). Migration and social policy in sub-Saharan Africa, in: United Nations Research Institute for Social Development (UNRISD), February 2008, http://www. unrisd.org/unrisd/website/document.nsf/(httpPublications)/AC96A6E2D6C0FF9CC 125751200354DDB?OpenDocument (15 July 14).

Gemeente Amsterdam (2006). Overige niet-westerse allochtonen in Amsterdam. Amsterdam: Dienst Onderzoek en Statistiek (Fact sheet, nr 2).

Amuedo-Dorantes, C. and Pozo, S. (2006). Remittances as insurance: evidence from Mexican immigrants, Journal of Population Economics, 19 (2): 227-254, doi: 10.1007/ s00148-006-0079-6.

Bertoli, S. and Marchetta, F. (2014). Migration, Remittances and Poverty in Ecuador, The Journal of Development Studies, 50 (8): 1067-1089, doi: 10.1080/00220388.2014.919382.

Datta, K., Mcllwaine, C., Wills, J., Evans, Y., Herbert, J. and May, J. (2006). Challenging Remittances as the New Development Mantra: Perspectives from Low-paid Migrant Workers in London. London: Queen Mary, University of London.

Dietz, K., Mazzucato, V., Kabki, M. and Smith, L. (2011). Ghanaians in Amsterdam, their "good work back home" and the importance of reciprocity, Journal of Global Initiatives, 6 (1): 132-143. 
Flick, U., Kardoff, E. v. and Steink, I. (eds) (2004). A Companion to Qualitative Research. London: Sage.

Freund, C. and Spatafora, N. (2008). Remittances, transaction costs, and informality, Journal of Development Economics, 86 (2): 356-366, doi: 10.1016/j.jdeveco.2007.09.002.

Goldring, L. (2004). Family and collective remittances to Mexico: a multidimensional typology, Development and Change, 35 (4): 799-840, doi: 10.1111/j.0012155X.2004.00380.x.

Jennissen, R. (2007). Causality Chains in the International Migration Systems Approach, Population Research and Policy Review, 26 (4): 411-436.

Kabki, M., Mazzucato, V. and Appiah, E. (2004). "Wo benane a eye bebree": the Economic Impact of Remittances of Netherlands-based Ghanaian Migrants on Rural Ashanti, Population, Space and Place, 10 (2): 85-97, doi: 10.1002/psp.323.

Karraker, M. W. (2013). Introduction: Global Migration in the Twenty-First Century, in: M. W. Karraker (ed.). The Other People. New York: Palgrave Macmillan, 3-23.

Lindley, A. (2009). The North-South Divide in Everyday Life: Londoners sending money "home", Bildhaan: an International Journal of Somali Studies, 9: 39-62.

Mazzucato, V. (2009). Informal Insurance Arrangements in Ghanaian Migrants' Transnational Networks: the Role of Reverse Remittances and Geographic Proximity, World Development, 37 (6): 1105-1115, doi: 10.1016/j.worlddev.2008.11.001.

Mazzucato, V. (2011). Reverse remittances in the migration-development nexus: twoway flows between Ghana and the Netherlands, Population, Space and Place, 17 (5): 454-468, doi: 10.1002/psp.646.

Mazzucato, V., Boom, B. van den and Nsowah-Nuamah, N. (2008). Remittances in Ghana: origin, destination and issues of measurement, International Migration, 46 (1): 103-122, doi: 10.1111/j.1468-2435.2008.00438.x.

McHugh, K. E. (2000). Inside, outside, upside down, backward, forward, round and round: a case for ethnographic studies in migration, Progress in Human Geography, 24 (1): 71-89, doi: 10.1191/030913200674985472.

Orozco, M. and Mohogu, M. (2007). Ghanaian Remitters in the Netherlands: A Preliminary Overview. Survey Commissioned by Oxfam-Novib, http://www.thedialogue.org/ PublicationFiles/FINAL_Ghanaian\%20Senders\%20Preliminary\%20Analysis_12-07. pdf (1 June 2014).

Osili, U. O. (2012). Understanding migrants' remittances: evidence from the US-Nigeria migration survey, in: M. Berriane and H. de Haas (eds). African Migrations ResearchInnovative Methods and Methodologies. Trenton: African World Press, 69-89.

Page, B. and Mercer, C. (2012). Why do people do stuff? Reconceptualizing remittance behaviour in diaspora-development research and policy, Progress in Development Studies, 12 (1): 1-18, doi: 10.1177/146499341101200101.

Pieke, F. N., Van Hear, N. and Lindley, A. (2007). Beyond control? The mechanics and dynamics of "informal" remittances between Europe and Africa, Global Networks, 7 (3): 348-366, doi: 10.1111/j.1471-0374.2007.00173.x.

Poirine, B. (2006). Remittances sent by a growing altruistic diaspora: how do they grow over time?, Asia Pacific Viewpoint, 47 (1): 93-108, doi: 10.1111/j.1467-8373.2006.00304.x.

Ponce, J., Olivié, I. and Onofa, M. (2008). Remittances for Development? A Case Study of the Impact of Remittances on Human Development in Ecuador, in: Real Instituto Elcano, July 2008, www.realinstitutoelcano.org/wps/portal/web (15 July 14). 
Stark, O. (1991). The Migration of Labor. Cambridge, Mass.: Basil Blackwell.

Stark, O. and Bloom, D. E. (1985). The New Economics of Labor Migration, American Economic Review, 75: 173-178.

Taylor, E. (1999). The new economics of labour migration and the role of remittances in the migration process, International Migration, 37 (1): 63-88, doi: 10.1111/14682435.00066 .

Teddlie, F., Charles, K. and Tashakkori, A. (eds) (2009). Foundations of Mixed Methods Research: Integrating Quantitative and Qualitative Approaches in the Social and Behavioural Sciences. London: Sage.

Vanwey, L. K. (2004). Altruistic and contractual remittances between male and female migrants and households in rural Thailand, Demography, 41 (4): 739-756.

Visser, S. S., B ailey, A . and Meijering, L. (2014). Food, faith and community: social wellbeing of Ghanaian migrants in the Netherlands, Gender, Place and Culture (Online), 21, doi: 10.1080/0966369X.2014.885891. 


\title{
Odavanje priznanja dvostrukim obvezama - strategije slanja novčanih doznaka ganskih migranata u Amsterdamu
}

\author{
Ntokozo Nzama, Brij Maharaj
}

\begin{abstract}
SAŽETAK
U radu se nastoji shvatiti zašto Ganci koji žive u Amsterdamu šalju novčane doznake te ispitati kako takva praksa utječe na njihov standard i životne uvjete u Amsterdamu u Nizozemskoj. Autori istražuju kako pošiljatelji snoseći žrtve i praveći kompromise, s obzirom na dvostruku odgovornost koju imaju - podupiranje obitelji u Gani i u Nizozemskoj, mogu održavati svoj životni stil u stranoj zemlji. U istraživanju je primijenjen kvalitativni pristup uz uporabu dubinskih intervjua kako bi se ispitanicima omogućilo da kao Ganci koji žive u stranoj zemlji otvoreno govore o svojim životnim iskustvima i izazovima povezanima sa slanjem novčanih doznaka. Na iseljavanje iz Gane utjecali su potisni čimbenici kao što su politički nemiri, siromaštvo, mali prihodi i nezaposlenost. Glavni privlačni čimbenik za dolazak u Nizozemsku bila je bolja kvaliteta života (bolje plaćeni poslovi i veće kvalifikacije). Doznake migranata iz Nizozemske pridonose boljitku mnogih kućanstava u Gani, osobito u pogledu poboljšanoga životnog standarda i lakšeg pristupa zdravstvenoj zaštiti i obrazovanju. Slanje novca nije samo »izraz dobre volje« nego i obveza prema članovima obitelji u Gani. Nalazi ove studije pokazuju da u načinu života ganskih migranata postoje veliki kompromisi s obzirom na njihovu dvostruku odgovornost.

KLJUČNE RIJEČI: migracija, novčane doznake, dvostruka obveza, Gana, Nizozemska
\end{abstract}

